\title{
Hemogasometric and biochemical changes caused by diets with high negative cation-anion balance in dairy cows
}

\section{Alterações hemogasométricas e bioquímicas causadas por dietas com alto balanço cátion-aniônico negativo em vacas leiteiras}

Josiane de Oliveira Feijó ${ }^{1}$ (D) , Uriel Secco Londero' (1D , Camila Pizoni' ${ }^{10}$, Joao Alveiro Alvarado-Rincón' (1) , Antônio Amaral Barbosa' (1) , Eduardo Schmitt (1), Rubens Alves Pereira ${ }^{1}\left[\right.$ D , Francisco Augusto Burkert Del Pino ${ }^{1}\left[\right.$ i , Marcio Nunes Corrêa $a^{1 *} \mathbb{D}$

${ }^{1}$ Universidade Federal de Pelotas, Pelotas, RS, Brazil

${ }^{*}$ Correspondent: marcio.nunescorrea@gmail.com

Received

January 21, 2021.

Accepted

June 22, 2021

Published

July 23, 2021.

www.revistas.ufg.br/vet

visit the website to get the

how to cite in the article page.

\begin{abstract}
This study aimed to evaluate hemogasometric and metabolic indicators in the first postpartum hours of dairy cows that received different cation-anion diets in the prepartum period. Holstein cows $(n=14)$, multiparous, were divided into two groups: (1) acidogenic diet (DA -27.13 mEq/100 g of DM) $(n=7)$ and (2) neutral diet (DN -3.25 mEq/100 g of DM) $(n=7)$, provided from 30 days before the expected calving. Urine samples were collected every three days from the beginning of supplementation until the day of delivery for $\mathrm{pH}$ verification. Blood samples were collected at 0, 6, 12, 24, 36, 48, 60 and 72 h postpartum for hemogasometric and biochemical analyses. The animals that received DA presented lower urinary $\mathrm{pH}$. The serum concentration of total calcium, ionized calcium and the incidence of subclinical hypocalcemia did not differ between groups. Animals that received DA presented reduction in blood levels of total plasma proteins, globulins, bicarbonate and blood $\mathrm{pH}$, in addition to increased activity of paraoxone-1 and reduction in the concentration of haptoglobin from animals of DN. In conclusion, we can infer that, anionic diets can alter blood $\mathrm{pH}$, interfere with protein synthesis, and probably improve antioxidant capacity.
\end{abstract}

Keywords: acid-base, subclinical hypocalcemia, hemogasometry, dairy cows.

\section{Resumo}

O objetivo deste estudo foi avaliar indicadores hemogasométricos e metabólicos nas primeiras horas pósparto de vacas leiteiras, que receberam diferentes dietas cátion-aniônica no pré-parto. Vacas da raça Holandesa Preta e Branca (HPB) ( $n=14)$, multíparas, foram divididas em dois grupos: dieta acidogênica (DA -27,13 mEq/100g de MS) ( $n=7)$ e dieta neutra (DN -3,25 mEq/100g de MS) ( $n=7)$, fornecidas a partir de 30 dias antes da previsão do parto. Amostras de urina foram coletadas a cada três dias após o início da suplementação até o dia do parto, para a verificação do $\mathrm{pH}$. 
Amostras de sangue foram coletadas às $0,6,12,24,36,48,60$ e 72 horas pós-parto, para análises hemogasométricas e bioquímicas. Os animais que receberam DA apresentaram $\mathrm{pH}$ urinário menor. A concentração sérica de cálcio total, cálcio ionizado e a incidência de hipocalcemia subclínica não diferiram entre os grupos. Animais que receberam DA apresentaram redução nos níveis sanguíneos de proteínas plasmáticas totais, globulinas, bicarbonato e $\mathrm{pH}$ sanguíneo, além de aumento na atividade de paraoxonase-1 (PON-1) e redução na concentração de haptoglobina em relação aos animais da DN. Como conclusão podemos inferir que, dietas acidogênicas podem alterar o pH sanguíneo, interferir na síntese de proteínas, e provavelmente melhorar a capacidade antioxidante.

Palavras-Chave: ácido-base, hipocalcemia subclínica, hemogasometria, vacas leiteiras.

\section{Introduction}

Diets with different cation-anionic balance (DCAB) are used at different periods during the productive life of dairy cows, such as the dry period, pre- and postpartum ${ }^{(1,2)}$. Currently, the acidogenic diet provided before delivery is used to prevent hypocalcemia, characterized by serum $\mathrm{Ca}_{\mathrm{t}}<8.0 \mathrm{mg} / \mathrm{dL}$ and/or $\mathrm{Ca}_{\mathrm{i}}<4.0 \mathrm{mg} / \mathrm{dL}^{(3-5)}$. Its action is based on the supply of anionic salts with the objective of reducing $\operatorname{DCAB}^{(6,7)}$.

The DCAB represents the difference between the cations ( $\mathrm{Na}^{+}$sodium, $\mathrm{K}^{+}$potassium) and the anions (Chlorine $\mathrm{Cl}^{-}$and sulfur SO4) present in the diet, in milliequivalents $(\mathrm{mEq})$ of $\left(\mathrm{Na}^{+}+\mathrm{K}^{+}\right)-\left(\mathrm{Cl}^{-}+\mathrm{SO} 4\right)$ per $100 \mathrm{~g}$ of dry matter (DM). To obtain an adequate acidogenic diet it is necessary that the sum of its ingredients is approximately -10 to $-20 \mathrm{mEq} / 100 \mathrm{~g}$ of $\mathrm{DM}^{(8)}$. Its main action is to decrease the blood $\mathrm{pH}$ and, consequently, activate the calcium homeostatic mechanism, which occurs due to the increased sensitivity of calcium receptors in the parathyroid, which increases the secretion of parathyroid hormone(9).

The effectiveness of blood acidification can be confirmed by the urinary $\mathrm{pH}$, which can be verified from 48 hours after the change in diet, with values below 6.8 indicating the correct administration of anionic salts ${ }^{(10)}$. The use of these salts for 11 days already promotes the homeostatic activation of calcium in the postpartum of dairy cows ${ }^{(11)}$. However, in production systems, the acidogenic diet is usually indicated for a minimum period of 21 days before the calving is expected(12,13), due to the uncertainty of the calving date.

During the peripartum period of the dairy cow, the requirement for calcium varies: in the prepartum, about 30 to 50g/day are needed, directed to the fetus, mammary gland (colostrum in the prepartum and milk in the postpartum) and its maintenance; in the immediate postpartum period, daily requirement can reach $100 \mathrm{~g}$ of calcium/day ${ }^{(6,14,15)}$. Depending on the production of colostrum and milk, calcium secretion can reach up to $2.3 \mathrm{~g} / \mathrm{L}$ only in colostrum, and in a cow that produces $40 \mathrm{~L}$ of milk/day, the secreted calcium can be 7 to 10 times higher than the levels of ionized calcium $\left(\mathrm{Ca}_{\mathrm{i}}\right)$ available 
in the body, predisposing to hypocalcemia(16, 17). To maintain the physiological levels of circulating total calcium $\left(\mathrm{Ca}_{\mathrm{t}}\right)$ it is necessary for the body to activate homeostatic mechanisms, a process that can take up to 72 hours, predisposing the animal to subclinical hypocalcemia, which can progress to clinical conditions and even death ${ }^{(6,16)}$.

Subclinical hypocalcemia can cause a cascade of events such as decreased DM intake (DMI), placental retention, uterine prolapse, abomasal displacement, ketosis, metritis and reduced reproductive performance ${ }^{(18-21)}$, which harms the health and productivity of the animal. The decrease in blood calcium levels can also cause a reduction in your cellular reserves, which directly impairs the immune response, contributing to a state of immunosuppression ${ }^{(18,22)}$. For this reason, it is necessary to prevent this disorder, with the acidogenic diet being the most used strategy. Even with its supply, the prevalence of hypocalcemia is high, reaching more than half of the animals, depending on the number of lactations and the level of milk production ${ }^{(23-25)}$.

PON-1 is a negative acute-phase protein produced by the liver, with the ability to prevent the oxidation of HDL and LDL, ability to hydrolyze xenobiotic organophosphates, protection from free radicals by limiting the oxidation of phospholipids and inhibition of peroxide production ${ }^{(26)}$. PON-1 is quite stable under normal conditions, but during inflammatory events or chronic liver disease, its levels decrease ${ }^{(27)}$. Haptoglobin, on the other hand, is one of the most sensitive positive acute-phase proteins in cattle, with anti-inflammatory and immunomodulatory properties (28), it can increase its plasma concentration by more than 100 times during infections ${ }^{(29)}$, in addition to having antioxidant properties, with the ability to bind to hemoglobin, inhibiting the oxidative activity of the heme group ${ }^{(30)}$.

In light of the above, the study hypothesis is that highly acidogenic diets in the prepartum period can change hemogasometric and biochemical parameters in the postpartum, and the objective of this study was to evaluate the effects of different diets on the hemogasometric, mineral, protein and energy profile of dairy cows in the first hours postpartum that received different cation-anionic diets in the prepartum.

\section{Materials and methods}

This experiment was approved by the Animal Experimentation Ethics Committee (CEEA) of the Federal University of Pelotas (UFPel) registered under code 2563.

This study was carried out in a dairy farm in the south of Rio Grande do Sul, in the city of Rio Grande ( $32^{\circ} 16^{\prime} \mathrm{S}, 52^{\circ} 32^{\prime} \mathrm{L}$ ). Fourteen pregnant cows of the black and white Holstein breed, multiparous, between third and fourth lactation, with body condition score (BCS) between 3.0 and 3.5 were selected ${ }^{(31)}$. The cows remained in a semiextensive management regime, fed in a collective trough being offered the diet twice a day, and were randomly distributed into two groups: acidogenic diet (DA, $n=7)$ and neutral diet $(\mathrm{DN}, \mathrm{n}=7)$. In the DA group, the feeding was balanced to $-27.13 \mathrm{mEq} / 100 \mathrm{~g} \mathrm{MS}$, while in the DN group, the feeding was balanced to $-3 \mathrm{mEq} / 100 \mathrm{~g}$ MS. Both diets were given 30 days before delivery (Table 1). 
Table 1. Ingredients and nutritional composition of acidogenic and neutral diets provided to dairy cows during precalving

\begin{tabular}{|c|c|c|c|c|c|c|}
\hline Ingredients (\%) & Rice straw & Pasture & Concentrate* & Concentrate* & Silage & $\begin{array}{c}\text { DCAD }^{1} \\
\mathrm{mEq} / 100 \\
\mathrm{~g} \mathrm{MS}\end{array}$ \\
\hline Acidogenic diet & 33.4 & 25 & 41.6 & - & - & -27.13 \\
\hline Neutral diet & 16.8 & 8.3 & - & 41.6 & 33.3 & -3.25 \\
\hline \multicolumn{7}{|c|}{ Nutritional composition (\%) } \\
\hline Dry matter & 82.59 & 94.23 & 94.67 & 93.72 & 33.22 & \\
\hline Crude protein & 7.84 & 19.98 & 22.65 & 22.78 & 6.35 & \\
\hline$N^{2} F^{2}$ & 74.32 & 47.41 & 28.05 & 16.60 & 31.95 & \\
\hline $\mathrm{ADF}^{3}$ & 54.16 & 31.02 & 18.59 & 9.70 & 3.91 & \\
\hline Lignin & - & 2.95 & - & - & 7.76 & \\
\hline Lipids & 1.72 & 1.90 & 2.95 & 7.55 & 3.78 & \\
\hline Ashes & 17.08 & 11.50 & 9.46 & 12.14 & 4.32 & \\
\hline Calcium & - & 0.69 & 1.46 & 1.73 & 0.18 & \\
\hline Phosphorus & - & 0.29 & 0.82 & 1.26 & 0.23 & \\
\hline Potassium & - & 3.02 & 1.26 & 1.30 & 0.97 & \\
\hline Magnesium & - & 0.18 & 0.61 & 0.73 & 0.18 & \\
\hline Sulfur & - & 0.20 & 1.05 & 0.90 & 0.10 & \\
\hline
\end{tabular}

*Concentrate composed of 33.7\% Ground Corn, 28\% Soy Bran, 30\% Rice Bran, 3.3\% Limestone, 4\% Anionic Salt and 1\% Vitamin Premix. 1 Cation-Anionic Balance Difference. 2 Neutral Detergent Fiber. 3Acid Detergent Fiber.

Urine $\mathrm{pH}$ was analyzed at prepartum using a bench pH meter (Tecnopon, PA-210-SP, Brazil) every three days from the beginning of supplementation, before supplementation. The bromatological and mineral analysis of the diet (pasture, silage and concentrate) provided for the different groups was carried out in a commercial laboratory (3rLab Minas Gerais, Brazil) using the NIRS method (Near Infrared spectroscopy).

Blood samples were collected through puncture of the coccygeal artery complex in tubes without anticoagulant (BD Diagnostics, São Paulo, Brazil), at $21 \pm 6$ days before calving (collection -1), and at 0, 6, 12, 24, 36, 48, 60 and 72h postpartum. Blood samples were centrifuged at $1800 \times \mathrm{g}$ for $15 \mathrm{~min}$ to obtain serum, and frozen at $-80^{\circ} \mathrm{C}$ for further analysis. 
Serum concentrations of total calcium (Cat), magnesium, albumin, urea, total plasmatic proteins (TPP) and creatinine were analyzed using commercial kits (Labtest Diagnóstica $\mathrm{SA}, \mathrm{Brazil}$ ) in automated biochemical equipment (Labmax Plenno- Labtest Diagnóstica SA, Brazil). Globulin levels were estimated using the formula (Globulins = TPP - albumin).

To check the serum concentration of ionized calcium ( $\left.\mathrm{Ca}_{\mathrm{i}}\right)$, $\mathrm{pH}$ (ionic hydrogen potential), bicarbonate, $\mathrm{pCO}_{2}$ (partial pressure of carbon dioxide), $\mathrm{pO}_{2}$ (oxygen pressure), $\mathrm{sO}_{2}$ (oxygen saturation), $\mathrm{TCO}_{2}$ (carbon dioxide content), $\mathrm{Na}^{+}$(sodium), $\mathrm{K}^{+}$(potassium), hemoglobin, hematocrit and glucose, the portable biochemical meter I-Stat (Aboot -USA) using GC+8 cartridges was used. Immediately after blood collections via the coccygeal vein in heparinized vacutainer tubes (BD Diagnostics, São Paulo, Brazil), the CG8+ cartridge was filled with blood and the reading was verified in the I-Stat. Animals with $\mathrm{Ca}_{\mathrm{i}}$ levels $\leq 4.0 \mathrm{mg} / \mathrm{dL}$ at least three times postpartum, at any time of collection, were considered to have subclinical hypocalcemia ${ }^{(5,6)}$.

Haptoglobin concentration was analyzed by colorimetric technique as described by Jones and Mould(32) and adapted by Schneider et al., ${ }^{(33)}$ using a microplate reader (Thermo Plate ${ }^{\circledR}$ TP-Reader, São Paulo, Brazil). The activity of paraoxonase-1 (PON-1) was analyzed by kinetic method through a protocol previously described by Browne et al., (34), and the reading performed in an ultraviolet light spectrophotometer (FEMTO Cirrus 80MB, FEMTO Indústria e Comércio de Instrumentos, São Paulo, Brazil).

Statistical analysis was performed using SAS software version 9.1 (SAS ® Institute Inc., Cary, NC, USA, 2009). Blood concentrations of all metabolites and hemogasometric indices were analyzed by the method of variance (ANOVA) with the MIXED procedure to assess the effect of group and hours and their interactions, Fisher's exact test to assess the frequency of subclinical hypocalcemia and descriptive statistics to analyze the urinary $\mathrm{pH}$. Statistical difference was considered $\mathrm{p}<0.05$. All results are presented in Mean \pm Standard Error of Mean (SEM).

\section{Results}

The urinary $\mathrm{pH}$ of animals that received DA was $5.9 \pm 0.13$, while in animals that received DN the $\mathrm{pH}$ was $7.4 \pm 0.24$.

No animal had clinical hypocalcemia during the study. When evaluating the incidence of subclinical hypocalcemia (Cai $\leq 4.0 \mathrm{mg} / \mathrm{dL}$ ) (5), 71.4\% (5/7) of the animals that received DN and $42.9 \%$ (3/7) of those that received DA presented the subclinical picture, however, the concentrations of $\mathrm{Ca}_{\mathrm{i}}$ (Figure $1 \mathrm{~A}$ ) and $\mathrm{Ca}_{\mathrm{t}}$ (Figure 1B) did not differ between groups $(p=0.46$ and $p=0.76$, respectively, Table 2$)$. 

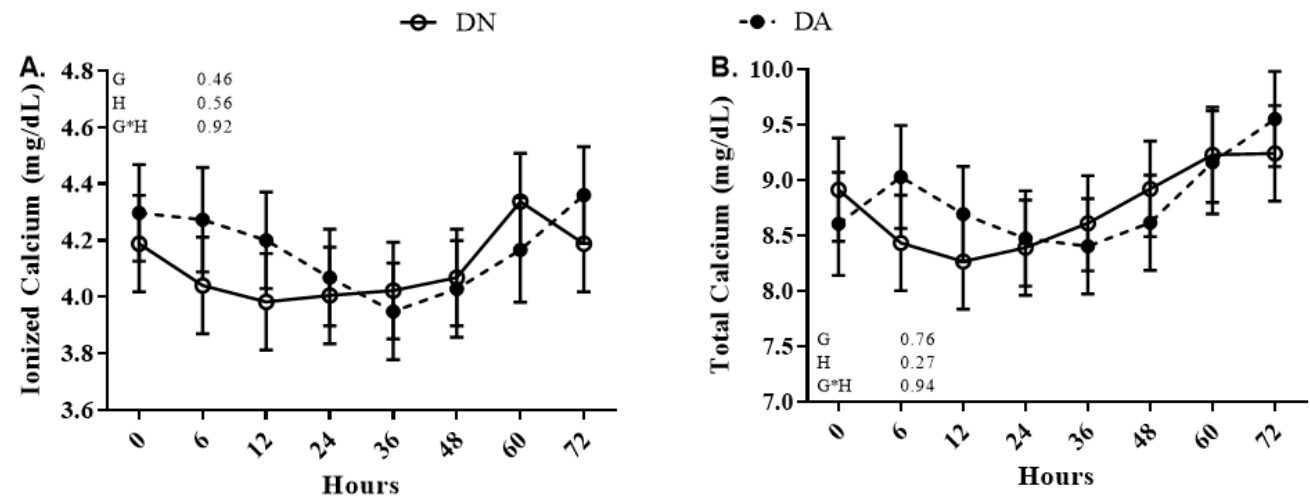

Figure 1. Means \pm standard error of the mean concentration of ionized calcium (A) and total calcium (B) of dairy cows in the first hours after parturition, submitted to neutral or acidogenic diets in the prepartum period. DA Acidogenic Diet; $\mathrm{DN}$ - Neutral Diet; $\mathrm{G}=$ Groups; $\mathrm{H}=$ hours; $\mathrm{G} * \mathrm{H}=$ interaction between groups and hours

Table 2. Metabolic and hemogasometric parameters (Mean \pm SEM) of dairy cows that received acidogenic diet (DA $-27.13 \mathrm{mEq} / 100 \mathrm{~g} \mathrm{DM}$ ) or neutral diet (DN $-3.25 \mathrm{mEq} / 100 \mathrm{~g} \mathrm{DM}$ ) in the prepartum period

\begin{tabular}{|c|c|c|c|c|c|}
\hline \multirow{2}{*}{$\begin{array}{c}\text { Parameters } \\
\text { Metabolics }\end{array}$} & \multicolumn{2}{|c|}{ Groups } & \multicolumn{3}{|c|}{ p values } \\
\hline & DA & DN & Group & Hour & $G * H$ \\
\hline Total calcium (mg/dL) & $8.82 \pm 0.15$ & $8.75 \pm 0.15$ & 0.76 & 0.27 & 0.95 \\
\hline Ionized calcium (mg/dL) & $4.17 \pm 0.06$ & $4.10 \pm 0.06$ & 0.46 & 0.56 & 0.93 \\
\hline Magnesium (mg/dL) & $2.03 \pm 0.05$ & $2.12 \pm 0.05$ & 0.19 & $<0.01$ & 0.99 \\
\hline Sodium (mmol/L) & $144.76 \pm 0.30$ & $143.59 \pm 0.30$ & 0.01 & $<0.01$ & 0.72 \\
\hline Potassium (mmol/L) & $4.50 \pm 0.06$ & $4.39 \pm 0.06$ & 0.22 & 0.08 & 0.98 \\
\hline Glucose (mg/dL) & $58.50 \pm 1.37$ & $62.14 \pm 1.33$ & 0.06 & $<0.01$ & 0.52 \\
\hline $\operatorname{TPP}^{1}(\mathrm{~g} / \mathrm{dL})$ & $7.41 \pm 0.06$ & $7.74 \pm 0.06$ & $<0.01$ & 0.87 & 0.96 \\
\hline Albumin (g/dL) & $2.96 \pm 0.04$ & $3.08 \pm 0.04$ & 0.05 & 0.14 & 0.6 \\
\hline Globulins (g/dL) & $4.44 \pm 0.07$ & $4.66 \pm 0.07$ & 0.03 & 0.76 & 0.98 \\
\hline Paraoxonase-1 (U/mL) & $83.14 \pm 3.60$ & $69.02 \pm 3.34$ & $<0.01$ & 0.89 & 0.67 \\
\hline Haptoglobin (g/L) & $0.32 \pm 0.04$ & $0.43 \pm 0.04$ & 0.07 & $<0.01$ & 0.06 \\
\hline Urea (mg/dL) & $55.85 \pm 0.30$ & $52.90 \pm 1.99$ & 0.30 & $<0.01$ & 0.57 \\
\hline Creatinin (mg/dL) & $1.39 \pm 0.04$ & $1.40 \pm 0.04$ & 0.89 & 0.04 & 0.64 \\
\hline \multicolumn{6}{|l|}{ Hemogasométricos } \\
\hline Blood pH & $7.37 \pm 0.01$ & $7.41 \pm 0.01$ & 0.01 & $<0.01$ & 0.94 \\
\hline $\mathrm{CO}_{2}$ pressure $(\mathrm{mmHg})$ & $44.10 \pm 1.09$ & $44.27 \pm 1.05$ & 0.92 & 0.99 & 0.92 \\
\hline Bicarbonate (mmol/L) & $26.92 \pm 0.47$ & $28.62 \pm 0.46$ & 0.02 & $<0.01$ & 0.96 \\
\hline Total $\mathrm{CO}_{2}(\mathrm{mmol} / \mathrm{L})$ & $28.45 \pm 0.52$ & $29.81 \pm 0.49$ & 0.05 & $<0.01$ & 0.99 \\
\hline $\mathrm{O}_{2}$ pressure $(\mathrm{mmHg})$ & $51.71 \pm 3.13$ & $46.97 \pm 3.25$ & 0.29 & 0.75 & 0.63 \\
\hline $\mathrm{O}_{2}$ saturation $(\%)$ & $82.51 \pm 2.28$ & $82.36 \pm 2.19$ & 0.46 & 0.56 & 0.57 \\
\hline Hematocrit (\%) & $25.57 \pm 0.28$ & $25.21 \pm 0.27$ & 0.36 & 0.24 & 0.91 \\
\hline Hemoglobin (mg/dL) & $8.70 \pm 0.09$ & $8.57 \pm 0.09$ & 0.33 & 0.26 & 0.91 \\
\hline
\end{tabular}

${ }^{1}$ Total plasmatic proteins. 
Serum sodium levels were higher (144.76 \pm 0.30 vs. $143.59 \pm 0.30 ; p=0.01)$ and TPP concentrations were lower $(7.41 \pm 0.06$ vs. $7.74 \pm 0.06 ; p<0.01)$ in animals in the DA group. There was a decrease in GLOB concentrations ( $4.44 \pm 0.07$ vs. $4.66 \pm 0.07 ; p=0.01$ ), in blood $\mathrm{pH}(7.37 \pm 0.01 \mathrm{vs} .7 .41 \pm 0.01 ; \mathrm{p}=0.01)$ and in the bicarbonate concentration ( $26.92 \pm 0.47$ vs. $28.62 \pm 0.46 ; p=0.02$ ) in the animals of the DA group. The PON-1 activity was higher in the animals of the DA group (83.14 \pm 3.60 vs. $69.02 \pm 3.34 p<0.01)$, while the haptoglobin levels tended to be lower in these animals ( $0.32 \pm 0.04$ vs. $0.43 \pm 0.04$; $p=0.07$ ).

\section{Discussion}

The present study showed metabolic variations in the recent postpartum of dairy cows that received diets with different DCAB in the prepartum period. Santos et al.,(1) stated that animals with reduced urinary $\mathrm{pH}$ have a lower risk of hypocalcemia, however, Goff(6) stated that a reduction in urinary $\mathrm{pH}$ below 6.2 in Holstein cows for a prolonged period could cause severe metabolic acidosis, reducing the DMI.

Even though no difference was found in the incidence of subclinical hypocalcemia, the DA group had high rates similar to those reported by Seely et al., ${ }^{(35)}$, which presented more than half of the animals with the disorder, even with the administration of an acidogenic diet. Among the factors that can influence the prevalence of subclinical hypocalcemia are the number of lactations ${ }^{(23)}$, milk yield, breed(36), body condition score $^{(37)}$, age and previous hypocalcemia problems ${ }^{(38)}$, in addition to the low palatability of the salts used, which end up reducing the $\mathrm{DMI}{ }^{(39)}$. The decrease in IMS can further aggravate the disease and also predispose to secondary disorders ${ }^{(40)}$, it is necessary that the diets are adequate during the period, since when unbalanced, acidogenic diets tend to lower the urinary and blood pH too much, causing decompensated acidosis, compromising the animal organism ${ }^{(6)}$.

Blood pH can vary from 7.35 to 7.45 , and the concentration of bicarbonate, one of the main regulators of acid-base balance, is 19 to $24 \mathrm{mmol} / \mathrm{L}$ in the serum of animals with balanced $\mathrm{pH}$. When the $\mathrm{pH}$ decreases, the bicarbonate concentration tends to decrease as well, capturing $\mathrm{H}^{+}$ions, forming carbonic acid, so that a respiratory compensation occurs, decreasing the $\mathrm{pCO}_{2}^{(2)}$ In the present study, animals in the DA group showed a reduction in blood $\mathrm{pH}$ and also in urinary $\mathrm{pH}$, due to acidogenic diets having a high amount of chlorine and sulfur, and these elements tend to decrease the $\mathrm{pH}$ of the blood, and consequently of the urine ${ }^{(41)}$. Furthermore, during the period evaluated, there was a reduction in the concentration of TPP in this experimental group, which may be due to the reduction in the prolonged extracellular $\mathrm{pH}$ that the animals went through, due to the high load of anions present in the diet. This strategy may not be a good option, as it decreases the production of bicarbonate-dependent $\mathrm{H}^{+}$transport proteins, which may lead to a decrease in intracellular $\mathrm{pH}^{(42)}$, and consequently reduction in protein synthesis (in the transcription process), as described in humans ${ }^{(43)}$.

When the $\mathrm{pH}$ is lowered, the tendency is for the $\mathrm{Ca}_{\mathrm{i}}$ to increase in an attempt to help 
the body's buffer system. This Cai can be obtained by bone resorption, by the action of parathormone or even by the uncoupling of Cai from proteins, mainly from albumin ${ }^{(9,}$ ${ }^{44)}$. Although this study did not demonstrate a reduction in the subclinical hypocalcemia incidence in animals from the DA group, nor a change in the plasma concentrations of $\mathrm{Ca}_{\mathrm{i}}$ and $\mathrm{Ca}_{\mathrm{t}^{\prime}}$ the reduction in blood $\mathrm{pH}$ may help to better mobilize calcium for the homeostasis of the animal's body.

In this study, animals that received DA showed a reduction in serum globulin levels, which may be associated with improved immunity, since most of the globulins are immunoglobulins ${ }^{(45)}$. Furthermore, the higher PON-1 activity and lower haptoglobin concentration suggested that the animals in the DA group had a less severe inflammatory state than the DN group. Given the antioxidant potential of PON-1(27), animals that received DA may be less susceptible to the deleterious effects of oxidizing substances, maintaining the balance between oxidizing agents and antioxidants. Correlating with the present study, it can be said that oxidative processes have direct damage to all cells, ranging from damage to DNA components, alteration in protein function and intracellular metabolic processes ${ }^{(46)}$, leaving animals more susceptible to disease. This is demonstrated by Schneider et al.,(33), who observed that these proteins can be early disease markers, since they show alterations even in the prepartum of animals which developed metritis in the postpartum period.

Although calcium levels were reduced in animals that received DN, no change in plasma levels of $\mathrm{Ca}_{\mathrm{t}}$ or $\mathrm{Ca}_{\mathrm{i}}$ was observed between groups, and lower serum sodium levels were found in postpartum animals in the DN group. Sodium is an important regulator of plasma calcium levels, which is carried out by the sodium-calcium antiport system, where calcium reabsorbed in the distal tubules of the kidneys and in the gastrointestinal tract is released into the bloodstream by exchange with sodium molecules ${ }^{(47)}$. This mechanism is capable of releasing up to 5000 calcium ions per second(48).

\section{Conclusion}

This study demonstrated that the use of a diet with high negative DCAB was not able to reduce the incidence of subclinical hypocalcemia, and diets with high DCAB should be further evaluated, however, there was a better antioxidant protection for the body. More studies should be conducted with a larger sample size in order to better evaluate the results.

\section{Acknowledgment}

The authors thank the Center for Research, Teaching and Extension in Livestock (NUPEEC/UFPel) for the opportunity; Fazenda 4 Irmãos, located in Rio Grande-RS for the supply of animals; and the Coordination for the Improvement of Higher Education Personnel (CAPES) and the Scientific and Technological Development Council (CNPq) for the financial support of this study. 


\section{Conflict of interests}

The authors declare no conflict of interest.

\section{References}

1. Santos JEP, Lean IJ, Golder H, Block E. Meta-analysis of the effects of prepartum dietary cation-anion difference on performance and health of dairy cows. Journal of dairy science. 2019;102(3):2134-54.

2. Hu W, Murphy MR. Dietary cation-anion difference effects on performance and acid-base status of lactating dairy cows: A meta-analysis. Journal of dairy research. 2004;87(7):2222-9.

3. Oetzel GR. Effect of calcium chloride gel treatment in dairy cows on incidence of periparturient diseases. J Am Vet Med Assoc. 1996;209(5):958-61.

4. Goff JP. The monitoring, prevention, and treatment of milk fever and subclinical hypocalcemia in dairy cows. The Veterinary Journal. 2008;176(1):50-7.

5. Martinez N, Sinedino L, Bisinotto R, Ribeiro E, Gomes G, Lima F, et al. Effect of induced subclinical hypocalcemia on physiological responses and neutrophil function in dairy cows. Journal of dairy science. 2014;97(2):874-87.

6. Goff JP. Calcium and magnesium disorders. The veterinary clinics of North America: food animal practice. 2014;30(2):359-81, vi.

7. Eklund M. The dietary cation-anion difference and its impact on the milk production in dairy cows. 2016.

8. Roche JR, Dalley DE, O'Mara FP. Effect of a metabolically created systemic acidosis on calcium homeostasis and the diurnal variation in urine $\mathrm{pH}$ in the non-lactating pregnant dairy cow. Journal of dairy research. 2007;74(1):34-9.

9. Campion KL, McCormick WD, WarwickerJ, Khayat ME, Atkinson-Dell R, Steward MC, et al. Pathophysiologic Changes in Extracellular pH Modulate Parathyroid Calcium-Sensing Receptor Activity and Secretion via a Histidine-Independent Mechanism. Journal of the American Society of Nephrology. 2015;26(9):2163-71.

10. Chan PS, West JW, Bernard JK. Effect of prepartum dietary calcium on intake and serum and urinary mineral concentrations of cows. Journal of dairy science. 2006;89(2):704-13.

11. Pizoni C, Feijó JO, Londero US, Pereira RA, Corrêa MN, Brauner CC, et al. Parâmetros clínicos, hematológicos e bioquímicos de novilhas com hipocalcemia subclínica pré-parto suplementadas com dieta aniônica. Arquivo brasileiro de medicina veterinária e zootecnia. 2017;69(5):1130-8.

12. Oetzel GR. Meta-analysis of nutritional risk factors for milk fever in dairy cattle. Journal of dairy science. 1991;74(11):3900-12.

13. DeGaris PJ, Lean IJ. Milk fever in dairy cows: A review of pathophysiology and control principles. The veterinary journal. 2008;176(1):58-69.

14. Fox DG, Tylutki TP. Accounting for the effects of environment on the nutrient requirements of dairy cattle. Journal of dairy research. 1998;81(11):3085-95.

15. DeGaris PJ, Lean IJ, Rabiee AR, Heuer C. Effects of increasing days of exposure to prepartum transition diets on reproduction and health in dairy cows. Aust Vet J. 2010;88(3):84-92. 
Hemogasometric and biochemical changes caused by diets with high negative cation-anion balance in dairy cows Feijó j $O$ et al.

16. Caixeta LS, Ospina PA, Capel MB, Nydam DV. Association between subclinical hypocalcemia in the first 3 days of lactation and reproductive performance of dairy cows. Theriogenology. 2017;94:1-7.

17. Horst RL, GoffJP, Reinhardt TA. Adapting to the transition between gestation and lactation: differences between rat, human and dairy cow. Journal of mammary gland biology and neoplasia. 2005;10(2):141-56.

18. Martinez N, Risco CA, Lima FS, Bisinotto RS, Greco LF, Ribeiro ES, et al. Evaluation of peripartal calcium status, energetic profile, and neutrophil function in dairy cows at low or high risk of developing uterine disease. Journal of dairy science. 2012;95(12):7158-72.

19. LeBlanc SJ. Relationships between metabolism and neutrophil function in dairy cows in the peripartum period. Animal : an international journal of animal bioscience. 2020;14(S1):s44-s54.

20. Brozos C, Mavrogianni VS, Fthenakis GC. Treatment and control of peri-parturient metabolic diseases: pregnancy toxemia, hypocalcemia, hypomagnesemia. The veterinary clinics of North America: food animal practice. 2011;27(1):105-13.

21. Lean IJ, Santos JEP, Block E, Golder HM. Effects of prepartum dietary cation-anion difference intake on production and health of dairy cows: A meta-analysis. Journal of dairy science. 2019;102(3):2103-33.

22. Clemens RA, Lowell CA. Store-operated calcium signaling in neutrophils. Journal of leukocyte biology. 2015;98(4):497-502.

23. Reinhardt TA, Lippolis JD, McCluskey BJ, Goff JP, Horst RL. Prevalence of subclinical hypocalcemia in dairy herds. The Veterinary Journal. 2011;188(1):122-4.

24. Silva DC, Fernandes BD, Santos Lima JM, Rodrigues GP, Dias DLB, Oliveira Souza EJ, et al. Prevalence of subclinical hypocalcemia in dairy cows in the Sousa city micro-region, Paraíba state. Tropical animal health and production. 2019;51(1):221-7.

25. McArt J, Neves R. Association of transient, persistent, or delayed subclinical hypocalcemia with early lactation disease, removal, and milk yield in Holstein cows. Journal of dairy science. 2020;103(1):690-701.

26. Canales A, Sánchez-Muniz FJ. Paraoxonasa,i algo más que una enzima? Medicina Clínica. 2003;121(14):537-48.

27. Ferré N, Camps J, Prats E, Vilella E, Paul A, Figuera L, et al. Serum paraoxonase activity: a new additional test for the improved evaluation of chronic liver damage. Clinical chemistry. 2002;48(2):261-8.

28. Jelena A, Mirjana M, Desanka B, Svetlana I-M, Aleksandra U, Goran P, et al. Haptoglobin and the inflammatory and oxidative status in experimental diabetic rats: antioxidant role of haptoglobin. Journal of physiology and biochemistry. 2013;69(1):45-58.

29. Eckersall PD, Young FJ, McComb C, Hogarth CJ, Safi S, Weber A, et al. Acute phase proteins in serum and milk from dairy cows with clinical mastitis. The Veterinary record. 2001;148(2):35-41.

30. Tseng CF, Lin CC, Huang HY, Liu HC, Mao SJT. Antioxidant role of human haptoglobin. Proteomics. 2004;4(8):2221-8.

31. Hady PJ, Domecq JJ, Kaneene JB. Frequency and precision of body condition scoring in dairy cattle. Journal of dairy science. 1994;77(6):1543-7.

32. Jones GE, Mould DL. Adaptation of the guaiacol (peroxidase) test for haptoglobins to a microtitration plate system. Research in veterinary science. 1984;37(1):87.

33. Schneider A, Corrêa MN, Butler WR. Short communication: acute phase proteins in Holstein cows diagnosed with uterine infection. Research in veterinary science. 2013;95(1):269-71. 
34. Browne RW, Koury ST, Marion S, Wilding G, Muti P, Trevisan M. Accuracy and biological variation of human serum paraoxonase 1 activity and polymorphism (Q192R) by kinetic enzyme assay. Clin Chem. 2007;53(2):310-7.

35. Seely C, Leno B, Kerwin A, Overton T, McArt J. Association of subclinical hypocalcemia dynamics with dry matter intake, milk yield, and blood minerals during the periparturient period. Journal of Dairy Science. 2021;104(4):4692-702.

36. González F, Corrêa M, Silva S. Transtornos metabólicos nos animais domésticos. Félix H Díaz Gonzalez, Marcío Nunes Corrêa (e) Sérgio Ceroni da Silva-2 Ed-Porto Alegre: UFRGS. 2014:344.

37. Roche JR, Friggens NC, Kay JK, Fisher MW, Stafford KJ, Berry DP. Invited review: Body condition score and its association with dairy cow productivity, health, and welfare. Journal of dairy science. 2009;92(12):5769-801.

38. Hernández-Castellano LE, Hernandez LL, Weaver S, Bruckmaier RM. Increased serum serotonin improves parturient calcium homeostasis in dairy cows. Journal of dairy science. 2017;100(2):1580-7.

39. Moore SJ, VandeHaar MJ, Sharma BK, Pilbeam TE, Beede DK, Bucholtz HF, et al. Effects of altering dietary cation-anion difference on calcium and energy metabolism in peripartum cows. Journal of dairy research. 2000;83(9):2095-104.

40. van Knegsel ATM, Van den Brand H, Dijkstra J, Tamminga S, Kemp B. Effect of dietary energy source on energy balance, production, metabolic disorders and reproduction in lactating dairy cattle. Reproduction nutrition development. 2005;45(6):665-88.

41. Goff JP. Pathophysiology of calcium and phosphorus disorders. The veterinary clinics of North America: food animal practice. 2000;16(2):319-37.

42. Schreiber R. Ca 2+ signaling, intracellular $\mathrm{pH}$ and cell volume in cell proliferation. The Journal of membrane biology. 2005;205(3):129.

43. Lecker SH, Goldberg AL, Mitch WE. Protein degradation by the ubiquitin-proteasome pathway in normal and disease states. Journal of the American society of nephrology. 2006;17(7):1807-19.

44. Jackson JA, Hemken RW. Calcium and Cation-Anion Balance Effects on Feed Intake, Body Weight Gain, and Humoral Response of Dairy Calves. Journal of dairy science. 1994;77(5):1430-6.

45. Russell KE, Roussel AJ. Evaluation of the ruminant serum chemistry profile. Vet Clin North Am Food Anim Pract. 2007;23(3):403-26.

46. Sordillo LM, Aitken SL. Impact of oxidative stress on the health and immune function of dairy cattle. Veterinary immunology and immunopathology. 2009;128(1-3):104-9.

47. Eaton D, Pooler J. Fisiologia renal de Vander. Porto Alegre - RS - Brasil: Artmed Editora; 2015.

48. Carafoli E, Santella L, Branca D, Brini M. Generation, control, and processing of cellular calcium signals. Critical reviews in biochemistry and molecular biology. 2001;36(2):107-260. 